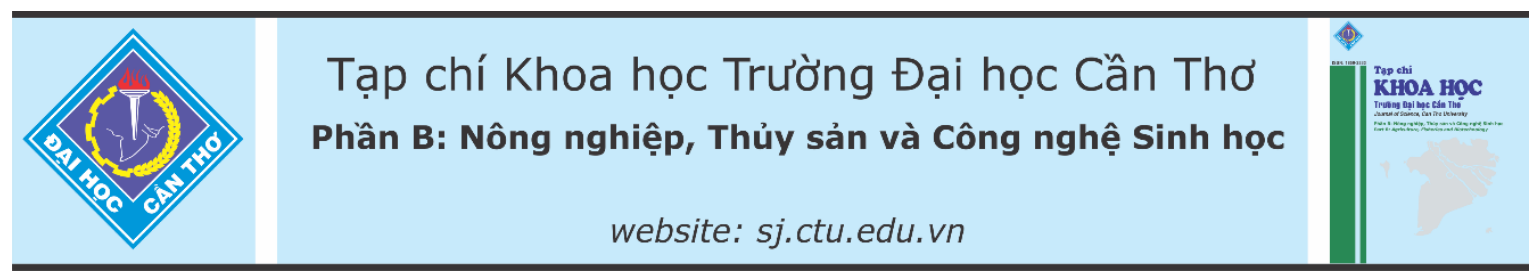

DOI:10.22144/ctu.jvn.2021.014

\title{
KHẢO SÁT HOẠT TÍNH KHÁNG NÂMM GÂY BỆNH THỐI TRÁI CỦA TINH DÂU QUẾ (Cinnamomum verum)
}

\author{
Thái Bảo ${ }^{1}$ và Đỗ Tấn Khang ${ }^{2 *}$ \\ ${ }^{1}$ Học viên Cao học, Ngành Vi sinh vật học, Khóa 27, Truòng Đại học Cần Tho' \\ ${ }^{2}$ Viện Nghiên cứu và Phát triển Công nghệ sinh học, Trưòng Đại học Cần Tho \\ *Nguoòi chịu trách nhiệm về bài viết: Đỗ Tấn Khang (email: dtkhang@ctu.edu.vn)
}

\section{Thông tin chung:}

Ngày nhận bài: 03/08/2020

Ngày nhận bài sủa: 21/11/2020

Ngày duyệt đăng: 27/02/2021

\section{Title:}

Evaluating inhibitory activity of cinnamon essential oil

(Cinnamomum verum) on fruitrotting fungi

\section{Tù khóa:}

Cinnamomum verum, kháng nấm, nấm gây thối trái, tinh dầu quế

\section{Keywords:}

Antifungal, cinnamon essential oil, Cinnamomum verum, fungi causing fruit rot

\begin{abstract}
This study was conducted to assess the inhibitory activity of cinnamon essential oil (Cinnamomum verum) on rotten pathogenic moulds isolated from strawberries, papaya, plums, and mangoes. Fungal strains were isolated on PDA and identified through colonial morphology, mycelia, spores, and ITS sequence. The antifungal activity of cinnamon essential oil was observed by agar disk diffusion method and dilution microbroth. The results revealed that four pathogenic fungi causing fruit rot include two fungal strains of Fusarium sp., one strain of Lasiodiplodia sp., and a strain of Diaporthe sp. Cinnamon essential oil completely inhibited the growth of mycelium of four fungal strains at the concentration of 0.4 $\mu L / m L$ by diffusing the essential oil in agar and completely prevent the germination of spores two strain Fusarium sp. by the dilution microbroth method. The MIC of essential oil with four isolated by diffusion method is $0.3-0.4 \mu \mathrm{L} / \mathrm{mL}$ and by dilution microbroth method is $0.4 \mu \mathrm{L} / \mathrm{mL}$ for TB1 and $0.2 \mu \mathrm{L} / \mathrm{mL}$ for the TB2. The MFC of essential oils is $0.3-0.6 \mu \mathrm{L} / \mathrm{mL}$.
\end{abstract}

\section{TÓM TẮT}

Nghiên cứu này được thực hiện với muc tiêu đánh giá hoạt tính ức chế của tinh dầu quế (Cinnamomum verum) đối với các dòng nấm mốc gây thối được phân lập tù̀ trái dâu tây, đu đủ, mận và xoài. Các dòng nấm được phân lập trên môi trường PDA, định danh thông qua hình thái khuẩn lạc, sợi nấm, bào tư và trình tụ ITS. Hoạt tính kháng nấm của tinh dầu quế được đánh giá bằng phưong pháp khuếch tán đĩa thạch và phuơng pháp vi lỏng. Kểt quả cho thấy bốn dòng nấm mốc gây thối trái bao gồm hai dòng nấm Fusarium sp., một dòng nấm Lasiodiplodia sp. và một dòng nấm Diaporthe sp. Tinh dầu quế ức chế hoàn toàn sụ tăng sinh sợi nấm của bốn dòng nấm ở nồng độ $0,4 \mu \mathrm{L} / \mathrm{mL}$ bằng phuơng pháp khuếch tán môi truòng thạch và ngăn chặn hoàn toàn bào tử nấm nảy mầm của hai dòng Fusarium sp. bằng phuoong pháp vi lỏng với cùng nồng độ. Giá trị MIC của tinh dầu đối với 4 dòng nấm bằng phuơng pháp khuêch tán đĩa thach là $0,3-0,4 \mu \mathrm{L} / \mathrm{mL}$ và bằng phuoong pháp vi lỏng là $0,4 \mu \mathrm{L} / \mathrm{mL}$ vớ $i$ dòng $T B 1$ và $0,2 \mu L / m L$ với dòng TB2. Giá trị $M F C$ của tinh dầu là $0,3-$ $0,6 \mu \mathrm{L} / \mathrm{mL}$ đối với các dòng nấm thông qua phuoong pháp khuếch tán đĩa thach và bằng phuoong pháp vi lỏng là $0,2-0,4 \mu \mathrm{L} / \mathrm{mL}$. 


\section{GIỚI THIÊU}

Việt Nam là nước có nền nông nghiệp phát triển trong đó sản xuất cây ăn quả đang có những bước phát triển đáng kể. Theo thống kê của Bộ Nông nghiệp và Phát triển Nông thôn (2016), nước ta có khoảng 863.000 ha trồng cây ăn trái các loại, trong đó các tỉnh, thành phía Nam chiếm trên dưới $50 \%$ khoảng 466.700 ha, riêng khu vực Đồng bằng sông Cửu Long có 288.500 ha là vùng chiếm diện tích lớn và là vựa trái cây lớn của cả nước, tuy nhiên, sản phẩm trái cây được tiêu thụ ở dạng tươi là chủ yếu ở tại địa phương và trong nước. Do trái cây có độ $\mathrm{pH}$ thấp, độ ẩm và chất dinh dưỡng cao rất dễ bị tấn công bởi nấm gây bệnh thối trái làm cho trái cây không sử dụng được và không thể bảo quản được lâu (Tripathi et al., 2008). Nấm mốc làm thối rữa các sản phẩm nông nghiệp là các loại hoa quả, điển hình nhu: Aspergillus spp., Penicillium spp., Monilinia spp,...không chỉ gây thối trái trong quá trình bảo quản sau thu hoạch mà nấm mốc còn sản xuất các độc tố như mycotoxin, aflatoxin,... gây bệnh cho người và động vật sử dụng (Chalutz and Wilson, 1990; Leong et al., 2004).

Hiện nay các biện pháp chủ yếu để kiểm soát sự phát triển, sinh tổng hợp độc tố và gây hư hỏng thực phẩm do nấm mốc được sử dụng là phương pháp vật lý, sinh học và hóa học. Tuy nhiên, việc phòng chống các loại nấm mốc gây hại chủ yếu là sử dụng các chất kháng nấm hóa học hoặc tổng hợp. Việc sử dụng quá nhiều các chất kháng nấm hóa học sẽ dẫn đến việc kháng thuốc của một số loại nấm, gây độc với con người và các loài sinh vật khác, làm ô nhiễm môi trường (Paster and Barkai, 2008; Raja, 2014). Từ đó, cần tìm một giải pháp mới an toàn, thân thiện với môi trường để giải quyết vấn đề nấm gây bệnh.

Trong những năm gần đây, việc sử dụng các hợp chất thiên nhiên đặc biệt được quan tâm. Một số nước đã dùng hợp chất được chiết xuất từ quế, đinh hương, cỏ xạ hương,... dùng xử lý nông sản trước khi bảo quản cũng có tác dụng ức chế quá trình phát triển của nấm mốc và độc tố của nấm (Fratianni $e t$ al., 2010). Một loạt các chất chiết xuất từ thực vật và các chất chuyển hóa thứ cấp như tinh dầu, tannin, alkaloids và flavonoid đã được báo cáo là có hoạt động chống lại một loạt các loại nấm in vitro (Simić et al., 2004; Wilson et al., 1999). Trong đó, tinh dầu là chất được sử dụng rộng rãi và lâu đời, một số lượng lớn các loại tinh dầu và thành phần của tinh dầu đã được nghiên cứu về đặc tính chống lại một số nấm.

\section{VẬT LIỆU VÀ PHƯƠNG PHÁP}

\subsection{Vật liệu}

Tinh dầu quế (Cinnamomum verum) được cung cấp từ Trung tâm Bảo tồn Giống dược liệu Hòa An, xã Xuân Hòa, huyện Kế Sách, tỉnh Sóc Trăng. Mẫu trái cây (dâu tây, đu đủ, mận và xoài) bị thối được thu trên địa bàn Thành phố Cần Thơ. Các thí nghiệm được tiến hành tại Phòng thí nghiệm Sinh học phân tử, Viện Nghiên cứu và Phát triển Công nghệ Sinh học, Trường Đại học Cần Thơ.

\subsection{Phương pháp}

2.2.1. Phân lập và định danh các dòng nấm gây thối trái

Mẫu trái thu về sau khi làm sạch bề mặt và được tiến hành phân lập nấm trên môi trường $\mathrm{PDA}$ và được ủ trong $48-72$ giờ ở trong bóng tối nhiệt độ $28^{\circ} \mathrm{C} \pm 2$. Kiểm tra bằng quan sát mắt thường và kính hiển vi về độ đồng nhất màu sắc và bề mặt khuẩn lạc nấm, hình dạng khuẩn ty.

Sau khi phân lập, các mẫu nấm được quan sát bằng mắt thường và kính hiển vi (Klich, 2002; Nguyễn Lê Anh Đào, 2012) về hình dạng tản nấm, hình dạng khuẩn ty, màu sắc khuẩn ty, màu sắc bào tử, hình dạng bào tử để tiến hành nhận diện sơ bộ. Nấm được nuôi cấy trên môi trường PDA trong 3 ngày ở điều kiện nhiệt độ phòng. Sau đó, thu tơ nấm và ly trích DNA theo Trần Nhân Dũng và $c t v$. (2012). Các mẫu nấm được khuếch đại với cặp mồi ITS1 và ITS4 (tác giả). Trình tự của ITS1 (mồi xuôi): 5'-TCCGTAGGTGAACCTGCGG-3'; ITS4 (mồi ngược): 5'-TCCTCCGCTTATTGATATGC3'. Sản phẩm PCR của các dòng nấm được giải trình tự theo phương pháp Sanger, sau đó so sánh trình tự thu được với trình tự trên ngân hàng gene $\mathrm{NCBI}$ để so sánh trình tự bộ gene và định danh nấm phân lập.

2.2.2. Xác định hoạt tính kháng nấm của tinh dầu quế bằng phuoong pháp khuếch tán đĩa thach

Đánh giá hoạt tính kháng nấm của tinh dầu quế được thực hiện bằng phương pháp khuếch tán trong môi trường thạch theo mô tả của Euloge et al. (2012). Nồng độ tinh dầu trong môi trường $(0,05$; 0,$1 ; 0,2 ; 0,3 ; 0,4 ; 0,5$ và $0,6 \mu \mathrm{L} / \mathrm{mL}$ ) đã được điều chỉnh bằng cách thêm lượng tinh dầu $C$. verum thích hợp được điều chỉnh bằng $0,5 \%(\mathrm{v} / \mathrm{v})$ Tween 80 vào môi trường PDA nóng chảy $\left(45^{\circ} \mathrm{C}\right)$, lắc đều để phân tán tinh dầu trong môi trường, tiến hành chia môi trường vào các đĩa Petri vô trùng (đường kính 80 $\mathrm{mm}$ ). Các khoanh nấm (đường kính $5 \mathrm{~mm}$ ) được cắt từ vùng rìa đang phát triển của đĩa nấm thuần đang 
nuôi cấy (sau 3 ngày) được chuyển vào trung tâm của đĩa Petri chứa môi trường có tinh dầu, các đĩa đối chứng (không có tinh dầu) được cấy theo cùng tối, nhiệt độ $28^{\circ} \mathrm{C} \pm 2$. Thí nghiệm lặp lại 3 lần. Đường kính khuẩn lạc nấm được đo sau 6 giờ/lần, kéo dài đến 120 giờ. Tỷ lệ phần trăm sự ức chế tăng trưởng sợi nấm bằng tinh dầu được tính theo công thức của Philippe et al. (2012):

Úc chế tăng trưởng sợi nấm $(\%)=\frac{\mathrm{dc}-\mathrm{dt}}{\mathrm{dc}} \mathrm{x} 100$

Trong đó:

dc: đường kính của khuẩn lạc mẫu đối chứng

dt: đường kính của khuẩn lạc trong mẫu chứa tinh dầu.

Nồng độ diệt nấm tối thiểu (MFC) của tinh dầu được xác định bằng cách cấy các đĩa nấm bị ức chế bởi tinh dầu không có sự sinh trưởng, phát triển khuẩn ty vào môi trường $\mathrm{PDA}$ (glucose $20 \mathrm{~g} / \mathrm{L}$, khoai tây $200 \mathrm{~g} / \mathrm{L}$, agar $20 \mathrm{~g} / \mathrm{L}, \mathrm{pH}=7$ ). Quan sát sự phát triển, sinh trưởng của các mẫu nấm sau khi ủ 72 giờ ở nhiệt độ $28^{\circ} \mathrm{C} \pm 2$. Nồng độ diệt nấm tối thiểu được xác định là nồng độ thấp nhất của tinh dầu mà tại nồng độ đó không có sự tăng trưởng xảy ra trên các đĩa sau khi cấy.

2.2.3. Xác định hoạt tính kháng nấm của tinh dầu quế bằng phương pháp vi lỏng và mật độ quang $(O D)$

Thí nghiệm đánh giá khả năng kháng nấm bằng tinh dầu được bố trí hoàn toàn ngẫu nhiên bằng các mẫu nấm gây thối trái được phân lập (Gakuubi et al., 2017). Chuẩn bị huyền phù bào tử nấm bằng cách cấy nấm trên môi trường PDA và ủ ở nhiệt độ phòng từ $5-7$ ngày để nấm sinh bào tử. Cho dung dịch $0,85 \% \mathrm{NaCl}$ vào ngập bề mặt nấm và khuấy nhẹ sau đó lọc dung dịch để thu nhận bào tử nấm và đếm mật số bào tử bằng buồng đếm hồng cầu và pha loãng về mật số $10^{5}$ bào tử/mL. Chuẩn bị môi trường nuôi lỏng: cho vào mỗi ống nghiệm $3,75 \mathrm{~mL}$ môi trường CZB (saccharose $30 \mathrm{~g} / \mathrm{L}$, sodium nitrate $3 \mathrm{~g} / \mathrm{L}$, một quy trình. Sau đó các đĩa nấm được ủ ở bóng

dipotassium phosphate $1 \mathrm{~g} / \mathrm{L}$, magnesium sulphate $0,5 \mathrm{~g} / \mathrm{L}$, potassium chloride $0,5 \mathrm{~g} / \mathrm{L}$, Ferrous sulphate $0,01 \mathrm{~g} / \mathrm{L}$ ) và được khử trùng ở $121^{\circ} \mathrm{C}, 1 \mathrm{~atm}$ trong 25 phút. Thêm vào ống nghiệm $0,75 \mathrm{~mL}$ tinh dầu được điều chỉnh bằng dung dịch Tween 80 nồng độ $0,5 \%(\mathrm{v} / \mathrm{v})$ để nồng độ tinh dầu trong môi trường lần lượt 0,$1 ; 0,2 ; 0,4 ; 0,6 ; 0,8$ và $1,0 \mu \mathrm{L} / \mathrm{mL}$. Các ống đối chứng âm lần lượt được cho $0,75 \mathrm{~mL}$ Tween 80 nồng độ $0,5 \% ; 0,75 \mathrm{~mL}$ nước cất và đối chứng dương thêm $0,75 \mathrm{~mL}$ acid gallic $500 \mu \mathrm{g} / \mathrm{mL}$ (Seo et al., 2013). Sau đó, chủng $3 \mathrm{~mL}$ dung dịch huyền phù bào tử nấm vào các ống nghiệm chứa môi trường đã được chuẩn bi và lắc ở nhiệt độ $28^{\circ} \mathrm{C}$. Giá trị quang được thu bằng cách hút $1000 \mu \mathrm{L}$ dung dịch ở mỗi bình đem đo $\mathrm{OD}$ ở bước sóng $\lambda=405 \mathrm{~nm}$ bằng máy đo quang phổ UV-Vis Evolution (Thermo, Mỹ) sau 12 giờ lắc (Rongai et al., 2012). Đo lần lượt dung dịch sau 12 giờ/lần và kéo dài trong 72 giờ. Mỗi lần đo lặp lại 3 lần.

Sau 72 giờ lắc, rút khoảng $50 \mu \mathrm{L}$ dịch nuôi cấy từ các ống nghiệm nuôi lỏng bào tử nấm và trải lên đĩa môi trường $\mathrm{PDA}$ và được ủ ở nhiệt độ $28^{\circ} \mathrm{C} \pm 2$ trong 3 ngày. Giá trị MFC được xác định là nồng độ tinh dầu thấp nhất cho thấy không có sự tăng trưởng hoặc ít hơn ba khuẩn lạc nấm (hoạt động tiêu diệt khoảng $99 \%$ đến $99,5 \%$ ) khi cấy trên môi trường đĩa thạch.

\subsubsection{Xủ lý số liệu}

Các số liệu được phân tích ANOVA bằng phần mềm Minitab 16, các giá trị trung bình được kiểm định bằng phép thử Tukey ở mức ý nghĩa $95 \%$.

\section{KẾT QUẢ VÀ THẢO LUẬN}

\subsection{Phân lập và định danh các dòng nấm gây thối trái}

Từ bốn mẫu trái cây bị thối, tiến hành phân lập được bốn dòng nấm mốc trên môi trường PDA. Sau ba ngày ủ, các đặc điểm về hình thái bên ngoài của các mẫu nấm được ghi nhận trong Bảng 1 và Bảng 2.

Bảng 1. Đặc điểm đại thể của khuẩn lạc nấm mốc trên môi trường PDA sau ba ngày

\begin{tabular}{|c|c|c|c|c|c|}
\hline $\begin{array}{l}\text { Tên dòng } \\
\text { nấm } \\
\end{array}$ & $\begin{array}{l}\text { Mẫu } \\
\text { trái }\end{array}$ & Hình dạng & Đặc điểm bề mặt & Màu sắc & $\begin{array}{c}\text { Đường kính } \\
(\mathbf{m m})\end{array}$ \\
\hline TB1 & Dâu tây & Tròn & $\begin{array}{l}\text { Tơ nấm mọc dày, phần rìa tơ nấm mọc } \\
\text { xoắn, có các vòng đồng tâm, khó thấm } \\
\text { nước }\end{array}$ & Màu trắng, tím nhạt & $29-32$ \\
\hline TB2 & Đu đủ & Tròn & Tơ nấm mịn, mọc xốp, nhô cao & Màu trắng, vàng cam & $28-32$ \\
\hline TB3 & Mận & Tròn & Khuẩn ty mịn, mọc dày và nhô cao & Màu trắng & $80-85$ \\
\hline TB4 & Xoài & Không đều & Khuẩn ty mọc lan & Màu trắng & $45-50$ \\
\hline
\end{tabular}


Theo quan sát hình thái đại thể và vi thể dưới kính hiển vi của dòng nấm $\mathrm{TB} 1$ và $\mathrm{TB} 2$ phân lập từ mẫu dâu tây và đu đủ phát triển trên môi trường PDA sau ba ngày, tản nấm phát triển hình dạng tròn có đường kính khoảng $30 \mathrm{~mm}$, hệ sợi nấm có vách ngăn, dạng sợi đa bào và tạo ra bào tử dài, có vách ngăn, hình liềm, thân cong, hai đầu thuôn nhọn (Hình 1 và Hình 2). Kết hợp với kết quả giải trình tự vùng ITS và so sánh với trình tự của các dòng nấm trong cơ sở dữ liệu Genebank của NCBI bằng công cụ Blast có độ tương đồng cao nhất là trên $98 \%$ đối với dòng $\mathrm{TB} 1$ và $91,75 \%$ đối với dòng nấm $\mathrm{TB} 2$ với các trình tự của các loài nấm thuộc chi Fusarium. Theo Summerell et al. (2003) và Hafizi et al. (2013) từ các kết quả về hình thái của bào tử, sợi nấm và tản nấm cũng như kết quả giải trình tự có sự tương đồng cao, có thể kết luận được dòng nấm $\mathrm{TB} 1$ và TB2 là Fusarium sp. Mehmood et al. (2017) đã báo cáo xác định mầm bệnh gây thối trái dâu tây ở Pakistan là Fusarium solani thông qua hình thái và sinh học phân tử. Zakaria et al. (2012) đã công bố Fusarium semitectum và $F$. solani là nguyên nhân chính gây nên thối trái đu đủ ở Malaysia.

\section{Bảng 2. Đặc điểm vi thể của nấm mốc trên môi trường PDA sau ba ngày}

\begin{tabular}{lll}
\hline Tên dòng & Khuẩn ty & Hình dạng bào tử \\
\hline TB1 & Phân nhánh, có vách ngăn & Bào tử có vách ngăn, hình liềm \\
TB2 & Phân nhánh, có vách ngăn & Bào tử vách ngăn, lưỡi liềm \\
TB3 & Phân nhánh, có vách ngăn & Bào tử hình tròn hoặc hình trứng, có vỏ dày, có vách ngăn \\
TB4 & Phân nhánh, có vách ngăn & Bào tử hình oval \\
\hline
\end{tabular}

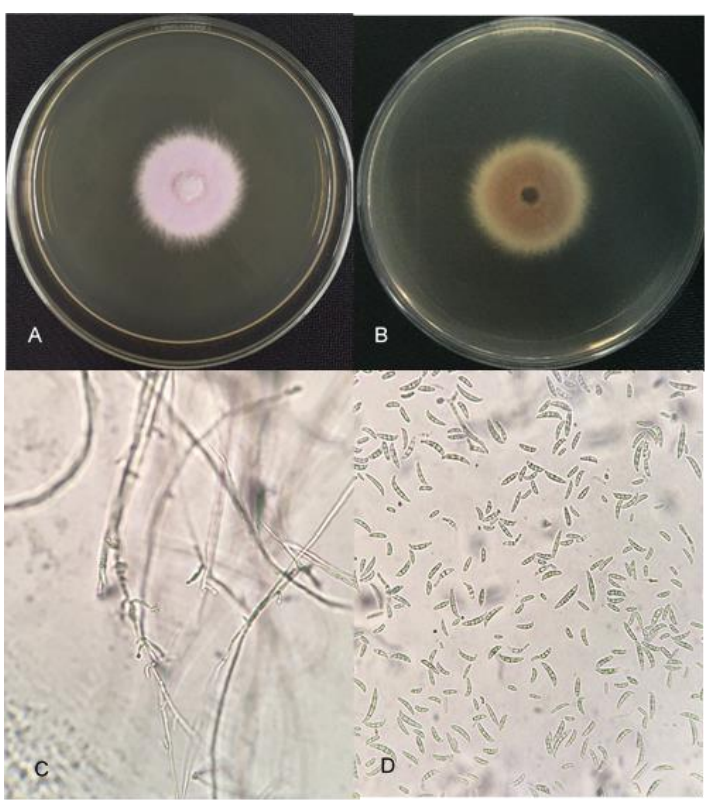

Hình 1. Hình dạng của dòng nấm TB1

(A: mặt trên khuẩn lạc, B: mặt duới khuẩn lạc,C: khuẩn ty ở vật kính 40X, D: bào tủ ở vật kính 40X)

Dòng nấm TB3 được phân lập từ mẫu mận có hệ sợi nấm phát triển rất nhanh, chỉ sau hai ngày nuôi cấy trên môi trường thạch PDA tơ nấm đã tràn khắp đĩa môi trường, không quan sát được hình dạng khuẩn lạc. Sợi nấm ban đầu màu trắng sau khoảng 14 ngày nuôi cấy chuyển sang màu nâu đen, có vách ngăn, phân nhánh. Bào tử của dòng nấm TB3 hình thành rất lâu trong quá trình nuôi cấy (khoảng sau 21 ngày); bào tử ban đầu chưa trưởng thành chưa hình thành vách ngăn còn bào tử trưởng thành có vách dày và có vách ngăn ngang (Hình 3 ). Kết quả giải trình tự vùng ITS của TB3 cho thấy có độ tương đồng cao nhất khi so sánh là $97,41 \%$ với loài nấm Lasiodiplodia thebromae và $97,2 \%$ với hai loài Lasiodiplodia brasilensis, Lasiodiplodia parva đều thuộc chi Lasiodiplodia phù hợp với các đặc điểm hình thái đã quan sát và kết hợp với nghiên cứu về hình thái của Phillips et al. (2005) và theo Damm et al. (2007), Lasiodiplodia plurivora là nguyên nhân gây bệnh thối trái nghiêm trọng đã làm mất sản lượng và chất lượng sau thu hoạch của mận, đào và cây xuân đào ở Nam Phi. Từ đó các kết quả trên có thể xác định dòng nấm TB3 là Lasiodiplodia sp.

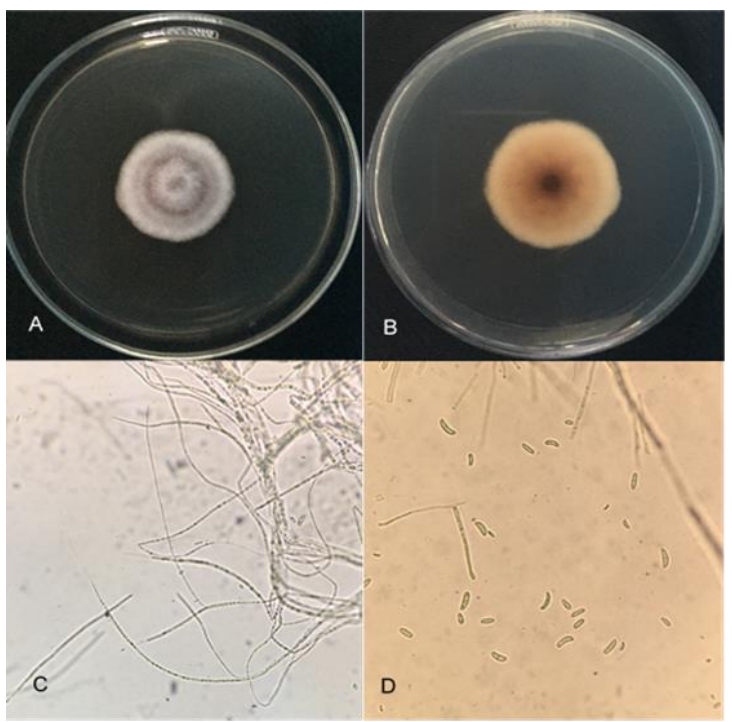

Hình 2. Hình dạng của dòng nấm TB2

(A: mặt trên khuẩn lạc, B: mặt duới khuẩn lạc,C: khuẩn ty ở vật kính 40X, D: bào tủ ở vật kính 40X) 


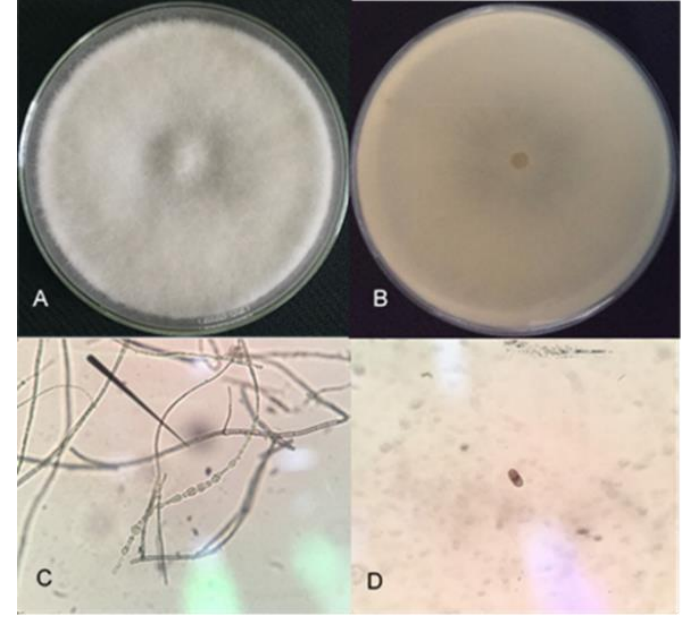

Hình 3. Hình dạng của dòng nấm TB3

(A: mặt trên khuẩn lạc, B: mặt duới khuẩn lạc,C: khuẩn ty ở vật kính $40 X$, D:bào tủ ở vật kính 40X)

Dòng nấm TB4 có hình dạng khuẩn lạc không đều, khuẩn ty có màu trắng, phần giữa mọc dày hơn, phần bìa mọc phẳng mặt môi trường,tơ nấm ngắn, không mịn, phát triển ra môi trường theo từng lớp tạo nên các khoảng sinh trưởng rõ rệt. Sợi nấm khi quan sát dưới kính hiển vi có vách ngăn, phân nhánh, sợi đa bào và bào tử hình elip đến oval, trong suốt và không có vách ngăn (Hình 4). So sánh trình tự vùng ITS của TB4 cho kết quả tương đồng cao nhất là $95,38 \%$ với Diaporthe spp. và theo Serrato-
Diaz et al. (2014), Diaporthe pseudomangiferae là mầm bệnh gây thối trái và hư hại hoa ở xoài nên có thể xác định dòng nấm TB4 là Diaporthe sp.

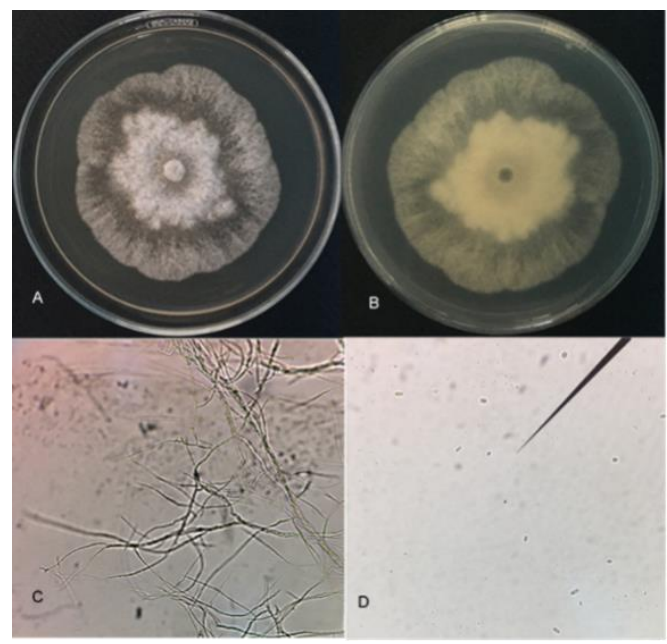

Hình 4. Hình dạng của dòng nấm TB4

(A: mặt trên khuẩn lac, B: mặt dưới khuẩn lạc,

C: khuẩn ty ở vật kính 40X, D: bào tủu ở vật kinh 40X)

\subsection{Hoạt tính kháng nấm của tinh dầu quế bằng phương pháp khuếch tán môi trường}

Kết quả khảo sát khả năng ức chế sinh trưởng sợi nấm của tinh dầu quế với bốn dòng nấm phân lập sau 48 giờ được ghi nhận kết quả trong Bảng 3 .

Bảng 3. Phần trăm ức chế sinh trưởng sợi nấm của tinh dầu quế tại thời điểm 48 giờ

\begin{tabular}{lrrrr}
\hline Nồng độ & \multicolumn{3}{c}{ Phần trăm ức chế sinh trưởng } \\
tinh dầu & TB1 & TB2 & TB3 & TB4 \\
\hline $0,05 \mu \mathrm{L} / \mathrm{mL}$ & $-6,67 \pm 3,33^{\mathrm{c}}$ & $21,86 \pm 1,44^{\mathrm{c}}$ & $0,00 \pm 0,00^{\mathrm{d}}$ & $5,34 \pm 2,17^{\mathrm{d}}$ \\
$0,1 \mu \mathrm{L} / \mathrm{mL}$ & $22,42 \pm 2,42^{\mathrm{b}}$ & $26,62 \pm 3,37^{\mathrm{c}}$ & $5,00 \pm 0,00^{\mathrm{d}}$ & $14,92 \pm 2,22^{\mathrm{c}}$ \\
$0,2 \mu \mathrm{L} / \mathrm{mL}$ & $25,61 \pm 5,86^{\mathrm{b}}$ & $46,90 \pm 2,84^{\mathrm{b}}$ & $20,42 \pm 0,42^{\mathrm{c}}$ & $67,04 \pm 3,45^{\mathrm{b}}$ \\
$0,3 \mu \mathrm{L} / \mathrm{mL}$ & $100^{\mathrm{a}^{*}}$ & $100^{\mathrm{a}^{*}}$ & $64,58 \pm 4,10^{\mathrm{b}}$ & $100^{\mathrm{a}^{*}}$ \\
$0,4 \mu \mathrm{L} / \mathrm{mL}$ & $100^{\mathrm{a}}$ & $100^{\mathrm{a}}$ & $100^{\mathrm{a}^{*}}$ & $100^{\mathrm{a}}$ \\
\hline
\end{tabular}

Giá trị là trung bình \pm sai số chuẩn của ba lần lạ̣p lại. Các chũ cái theo sau giống nhau trong cùng một hàng thì khác biệt không có ý nghĩa thống kê với kiểm định Tukey, mức ý nghĩa 95\%.

(-): Phần trăm kich thích tăng trương của tinh dầu đối với sinh trương của nấm

(*): Nồng độ ức chế tối thiểu (MIC) đối với các dòng nấm

Hoạt tính kháng nấm trên cả bốn dòng nấm cho thấy có đến ba dòng (TB1, TB2 và TB4) ngừng sinh trưởng hoàn toàn ở nồng độ $0,3 \mu \mathrm{L} / \mathrm{mL}$ và ổn định đến hết thời gian khảo sát. Riêng dòng nấm TB3 bị ức chế $64,58 \%$ ở nồng độ $0,3 \mu \mathrm{L} / \mathrm{mL}$, còn ở nồng độ $0,4 \mu \mathrm{L} / \mathrm{mL}$ ức chế hoàn toàn trong 48 giờ. Đặc biệt, ở nồng độ tinh dầu $0,05 \mu \mathrm{L} / \mathrm{mL}$, nấm TB1 có sự phát triển mạnh và vượt trội với phần trăm tăng trưởng từ $6,67 \%$ khi so sánh với nghiệm thức đối chứng và theo Pernak et al. (2013), các hoạt chất lỏng chứa ion như: 2-chloroethyltrimethylammonium và trimethylvinylammonium (2,4-dichlorophenoxy) acetates cho thấy hoạt động ức chế sự phát triển và diệt cỏ rất tốt khi sử dụng $440 \mathrm{~g} / \mathrm{ha}$ nhưng khi sử dụng hoạt chất trên với nồng độ $0,005 \mathrm{M}$ đến 0,01 $\mathrm{M}$ thì lại cho kết quả tăng khả năng sinh trưởng như một chất kích thích, điều hòa sinh trưởng thực vật. Vì vậy, ở nồng độ tinh dầu thấp $(0,05 \mu \mathrm{L} / \mathrm{mL})$ thì có khả năng là chất kích thích cho quá trình tăng trưởng sợi nấm của dòng nấm $\mathrm{TB} 1$. 
Nồng độ ức chế tối thiểu (MIC) của tinh dầu có sự tương đồng giữa dòng nấm TB1 (Fusarium $\mathrm{sp}$.), TB2 (Fusarium sp.) và TB4 (Diaporthe $\mathrm{sp}$.) đều là $0,3 \mu \mathrm{L} / \mathrm{mL}$. Giá trị $\mathrm{MIC}$ này cũng tương đương với MIC là $0,25 \mu \mathrm{L} / \mathrm{mL}$ khi thử nghiệm khả năng kháng nấm của các loại tinh dầu từ cây thuộc họ Lauraceae với các dòng nấm gây bệnh. Còn đối với dòng nấm TB3 (Lasiodiplodia sp.), MIC là $0,4 \mu \mathrm{L} / \mathrm{mL}$, thấp hơn MIC của tinh dầu trầm hương là $2 \mathrm{mg} / \mathrm{mL}$ khi đối kháng với nấm Lasiodiplodia theobromae (Zhang et al., 2014). Nghiên cứu kháng nấm của tinh dầu quế (Cinnamomum verum) đối với dòng nấm mốc Aspergillus fumigatus có giá trị MIC từ $\leq$ $0,04-0,31 \mu \mathrm{L} / \mathrm{mL}$ và với một số loài nấm men (Candida albicans, C. glabrata, C. parapsilosis, C. Tropicalis và Crytococcus neoformans) là 0,31 $0,63 \mu \mathrm{L} / \mathrm{mL}$ (Jantan et al., 2008). Nồng độ diệt nấm tối thiểu (MFC) của tinh dầu với các dòng nấm như dòng $\mathrm{TB} 1$ có giá trị $\mathrm{MFC}$ là $0,3 \mu \mathrm{L} / \mathrm{mL}$, dòng $\mathrm{TB} 2$ là $0,4 \mu \mathrm{L} / \mathrm{mL}$, dòng $\mathrm{TB} 3$ và TB4 là $0,6 \mu \mathrm{L} / \mathrm{mL}$.

\subsection{Hoạt tính kháng nấm của tinh dầu quế bằng phương pháp vi lỏng và mật độ quang $(\mathrm{OD})$}

Do hai dòng nấm $\mathrm{TB} 3$ và $\mathrm{TB} 4$ là những loài nấm tạo bào tử sau thời gian dài (khoảng 21 ngày) và số lượng bào tử được sinh ra ít nên chỉ hai dòng nấm $\mathrm{TB} 1$ và $\mathrm{TB} 2$ được sử dụng để tiến hành khảo sát bằng phương pháp nuôi lỏng.

Kết quả khảo sát khả năng ngăn sự nảy mầm của bào tử từ hai dòng nấm TB1 (Fusarium sp.) và TB2 (Fusarium sp.) của tinh dầu quế bằng phương pháp vi lỏng được đánh giá qua chỉ số mật độ quang ở bước sóng $\lambda=405 \mathrm{~nm}$ (Bảng 4).

Bảng 4. Giá trị mật độ quang $(\lambda=405 \mathrm{~nm})$ của hai dòng nấm TB1 và TB2

\begin{tabular}{lrr}
\hline \multirow{2}{*}{ Nghiệm thức } & Giá trị mật độ quang phổ $(\boldsymbol{\lambda}=\mathbf{4 0 5 n m})$ \\
\cline { 2 - 3 } & TB1 & TB2 \\
\hline ĐC dương (Gallic acid 500 $\mu \mathrm{g} / \mathrm{mL})$ & $0,55 \pm 0,04^{\mathrm{a}}$ & $0,54 \pm 0,01^{\mathrm{ab}}$ \\
ĐC âm (Nước cất khử trùng) & $1,19 \pm 0,22^{\mathrm{b}}$ & $1,55 \pm 0,25^{\mathrm{c}}$ \\
ĐC âm (Tween $80-0,5 \%)$ & $1,05 \pm 0,06^{\mathrm{b}}$ & $0,81 \pm 0,02^{\mathrm{b}}$ \\
$0,1 \mu \mathrm{L} / \mathrm{mL}$ & $1,20 \pm 0,06^{\mathrm{b}}$ & $0,56 \pm 0,10^{\mathrm{ab}}$ \\
$0,2 \mu \mathrm{L} / \mathrm{mL}$ & $1,04 \pm 0,07^{\mathrm{b}}$ & $0,22 \pm 0,00^{\mathrm{a}^{*}}$ \\
$0,4 \mu \mathrm{L} / \mathrm{mL}$ & $0,32 \pm 0,01^{\mathrm{a}^{*}}$ & $0,22 \pm 0,00^{\mathrm{a}}$ \\
$0,6 \mu \mathrm{L} / \mathrm{mL}$ & $0,29 \pm 0,01^{\mathrm{a}}$ & $0,24 \pm 0,02^{\mathrm{a}}$ \\
$0,8 \mu \mathrm{L} / \mathrm{mL}$ & $0,30 \pm 0,02^{\mathrm{a}}$ & $0,26 \pm 0,02^{\mathrm{a}}$ \\
$1,0 \mu \mathrm{L} / \mathrm{mL}$ & $0,34 \pm 0,01^{\mathrm{abc}}$ & $0,23 \pm 0,00^{\mathrm{a}}$ \\
\hline
\end{tabular}

Giá trị là trung bình \pm sai số chuẩn của ba lần lạ̣p lại. Các chũ cái theo sau giống nhau trong cùng một hàng thì khác biệt không có ý nghĩa thống kê với kiểm định Tukey, mức ý nghĩa 95\%.

(*): Nồng độ ức chế tối thiểu (MIC) đối với các dòng nấm

Tinh dầu quế có hoạt tính ngăn hoàn toàn bào tử nấm nảy mầm đối với hai dòng nấm $\mathrm{TB} 1$ và $\mathrm{TB} 2$ ở nồng độ tinh dầu khá thấp: $0,4 \mu \mathrm{L} / \mathrm{mL}$ với bào tử của dòng $\mathrm{TB} 1$ và $0,2 \mu \mathrm{L} / \mathrm{mL}$ đối với bào tử của dòng nấm TB2 ở trong suốt khoảng thời gian 72 giờ khảo sát. Tuy nhiên khi có tinh dầu với nồng độ 0,1 $\mu \mathrm{L} / \mathrm{mL}$ và $0,2 \mu \mathrm{L} / \mathrm{mL}$ trong môi trường thì đối với dòng TB1 là những chất kích thích, hỗ trợ quá trình nảy mầm và phát triển còn đối với dòng $\mathrm{TB} 2$ không có tác dụng mà có tác dụng ức chế. Từ đây có thể thấy dòng nấm TB2 nhạy cảm với tinh dầu quế hơn dòng nấm TB1 trong thí nghiệm môi trường lỏng. Giá trị $\mathrm{MIC}$ của hai dòng nấm $\mathrm{TB} 1$ và $\mathrm{TB} 2$ đối với tinh dầu cũng khác nhau lần lượt là $0,4 \mu \mathrm{L} / \mathrm{mL}$ và $0,2 \mu \mathrm{L} / \mathrm{mL}$. Kết quả này gần bằng với khảo sát của Simić et al. (2004) có giá trị MIC của tinh dầu quế (Cinnamomum sp.) là $0,25 \mu \mathrm{L} / \mathrm{mL}$ đối với nấm Fusarium spp. và thấp hơn giá trị MIC là $7-8$ $\mu \mathrm{L} / \mathrm{mL}$ khi sử dụng tinh dầu bạch đàn (Eucalyptus camaldulensis) trên nấm Fusarium spp. (Gakuubi et $a l$, 2017). Còn đối với nồng độ diệt nấm tối thiểu (MFC) của phương pháp vi lỏng đối dòng nấm TB1 và $\mathrm{TB} 2$ lần lượt là $0,4 \mu \mathrm{L} / \mathrm{mL}$ và $0,2 \mu \mathrm{L} / \mathrm{mL}$. Giá trị MIC của tinh dầu các cây thuộc chi quế (Cinnamomum spp.) là $0,25 \mu \mathrm{L} / \mathrm{mL}$ đối với nấm Fusarium spp. (Simić et al., 2004) và MIC là 7-8 $\mu \mathrm{L} / \mathrm{mL}$ khi sử dụng tinh dầu bạch đàn (Eucalyptus camaldulensis) trên nấm Fusarium spp. (Gakuubi et al., 2017); tinh dầu kinh giới (Origanum syriacum L.) có hoạt tính kháng nẩm chống lại Aspergillus niger, Fusarium oxysporum và Penicillium spp. với MIC là $0,1 \mu \mathrm{L} / \mathrm{mL}$ (Castro et al., 1995), tất cả các giá trị MIC của các nghiên cứu này tương đương hoặc cao hơn khi so với kết quả MIC được khảo sát.

Qua kết quả khảo sát hoạt tính kháng nấm của tinh dầu quế với 4 dòng nấm được phân lập, cho thấy tinh dầu có khả năng ức chế sự sinh trưởng sợi nấm và sự nảy mầm của bào tử nấm hiệu quả với nồng độ rất thấp $(0,2-0,4 \mu \mathrm{L} / \mathrm{mL})$. Từ đây cho thấy tiềm 
năng của việc áp dụng tinh dầu như một loại thuốc chống nấm sinh học rất cao để xử lý các bệnh liên quan với nấm gây bệnh trên trái sau thu hoạch.

\section{KẾT LUẬN}

Đề tài phân lập được bốn dòng trong đó hai dòng nấm Fusarium sp. (dâu tây, đu đủ), một dòng nấm Lasiodiplodia sp. (mận), một dòng nấm Diaporthe sp. (xoài) thuần chủng gây hại từ bốn mẫu trái cây thối gồm dâu tây, đu đủ, mận và xoài trên địa bàn Thành phố Cần Thơ.

Qua khảo sát khả năng ức chế tăng trưởng sợi nấm của tinh dầu quế, thu được kết quả tinh dầu quế ức chế hoàn toàn $100 \%$ sự tăng trưởng với hai dòng nấm Fusarium sp. (TB1 và $\mathrm{TB} 2$ ) và một dòng nấm Diaporthe sp. (TB4) ở nồng độ $0,3 \mu \mathrm{L} / \mathrm{mL}$; với dòng nấm Lasiodiplodia sp. (TB3) ở nồng độ $0,4 \mu \mathrm{L} / \mathrm{mL}$ sau 48 giờ. Tinh dầu quế có nồng độ ức chế tối thiểu (MIC) là $0,3-0,4 \mu \mathrm{L} / \mathrm{mL}$ và nồng độ diệt nấm tối thiểu (MFC) là $0,3-0,6 \mu \mathrm{L} / \mathrm{mL}$ khi khảo sát với bốn dòng nấm thử nghiệm bằng phương pháp khuếch tán đĩa thạch.

Thử nghiệm hoạt tính ức chế khả năng nảy mầm của bào tử hai dòng nấm Fusarium $\mathrm{sp}$. (TB1 và TB2) kết quả thu được tinh dầu quế ức chế hiệu quả khả năng nảy mầm của bào tử thuộc hai dòng nấm Fusarium sp. với nồng độ từ $0,4-1,0 \mu \mathrm{L} / \mathrm{mL}$ kéo dài trong 72 giờ. Nồng độ ức chế tối thiểu $(\mathrm{MIC})$ của tinh dầu quế đối với 2 dòng nấm là $0,4 \mu \mathrm{L} / \mathrm{mL}$ và nồng độ diệt nấm tối thiểu (MFC) được xác định là $0,4 \mu \mathrm{L} / \mathrm{mL}$ bằng phương pháp nuôi cấy vi lỏng.

\section{TÀI LIỆU THAM KHẢO}

Bộ Nông nghiệp và Phát triển Nông thôn (2016). Báo cáo kết quả thục hiện kế hoạch tháng 12 năm 2016 ngành Nông nghiệp và Phát triển Nông thôn. https://www.mard.gov.vn/ThongKe/Lists/BaoCaoT hongKe/Attachments/120/Baocao_T12_2016.pdf.

Castro, L. M. D. (2014). Atividade ovicida de Ocimum basilicum em nematódeos gastrintestinais de ovinos (Master's thesis). Universidade Federal de Pelotas.

Chalutz, E., \& Wilson, C. L. (1990). Postharvest biocontrol of green and blue mold and sour rot of citrus fruit by Debaryomyces hansenii. Plant disease, 74(2), 134-137.

Damm, U., Crous, P. W., \& Fourie, P. H. (2007). Botryosphaeriaceae as potential pathogens of Prunus species in South Africa, with descriptions of Diplodia africana and Lasiodiplodia plurivora sp. nov. Mycologia, 99(5), 664-680.

Euloge, S. A., Kouton, S., Dahouenon-Ahoussi, E., Sohounhloue, D. C. K., \& Soumanou, M. M. (2012). Antifungal activity of Ocimum canum essential oil against toxinogenic fungi isolated from peanut seeds in post-harvest in Benin. International Research Journal of Biological Sciences, 1(7), 20-26.

Fratianni, F., De Martino, L., Melone, A., De Feo, V., Coppola, R., \& Nazzaro, F. (2010). Preservation of chicken breast meat treated with thyme and balm essential oils. Journal of food science, 75(8), 528-535.

Gakuubi, M. M., Maina, A. W., \& Wagacha, J. M. (2017). Antifungal activity of essential oil of Eucalyptus camaldulensis dehnh. against selected Fusarium spp. International journal of microbiology, 2017.

Hafizi, R., Salleh, B., \& Latiffah, Z. (2013). Morphological and molecular characterization of Fusarium. solani and F. oxysporum associated with crown disease of oil palm. Brazilian Journal of Microbiology, 44(3), 959-968.

Jantan, I. B., Karim Moharam, B. A., Santhanam, J., \& Jamal, J. A. (2008). Correlation between chemical composition and antifungal activity of the essential oils of eight cinnamomum.

Species. Pharmaceutical Biology, 46(6), 406-412.

Klich, M. A. (2002). Identification of common Aspergillus species. The Netherlands.

Leong, S. L., Hocking, A. D., \& Pitt, J. I. (2004). Occurrence of fruit rot fungi (Aspergillus section Nigri) on some drying varieties of irrigated grapes. Australian Journal of Grape and Wine Research, 10(1), 83-88.

Mehmood, N., Riaz, A., Jabeen, N., Anwaar, S., Hussain, S. Z., Abbas, M. F., ... \& Gleason, M. L. (2017). First report of Fusarium solani causing fruit rot of strawberry in Pakistan. Plant Disease, 101(9), 1681-1681.

Nguyễn Lê Anh Đào (2012). Tuyển chọn các dòng nấm mốc Aspergillus spp. có khả năng phân hủy bã mía sau trồng nấm (Luận văn thạc sĩ). Trường Đại học Cần Thơ.

Paster, N., \& Barkai-Golan, R. (2008). Mouldy fruits and vegetables as a source of mycotoxins: part 2. World Mycotoxin Journal, 1(4), 385-396.

Pernak, J., Niemczak, M., Materna, K., Marcinkowska, K., \& Praczyk, T. (2013). Ionic liquids as herbicides and plant growth regulators. Tetrahedron, 69(23), 4665-4669.

Philippe, S., Souaïbou, F., Guy, A., Sébastien, D. T., Boniface, Y., Paulin, A., ... \& Dominique, S. (2012). Chemical Composition and Antifungal activity of Essential oil of Fresh leaves of Ocimum gratissimum from Benin against six Mycotoxigenic Fungi isolated from traditional cheese wagashi. Research Journal of Biological Sciences, 1, 22-27. 
Phillips, A., Alves, A., Correia, A., \& Luque, J. (2005). Two new species of Botryosphaeria with brown, 1-septate ascospores and Dothiorella anamorphs. Mycologia, 97(2), 513-529.

Raja, N. (2014). Botanicals: sources for eco-friendly biopesticides. Journal of Biofertilizers and Biopesticides, 5(1), 1.

Rongai, D., Milano, F., \& Sciò, E. (2012). Inhibitory effect of plant extracts on conidial germination of the phytopathogenic fungus Fusarium oxysporum.

Seo, D. J., Lee, H. B., Kim, I. S., Kim, K. Y., Park, R. D., \& Jung, W. J. (2013). Antifungal activity of gallic acid purified from Terminalia nigrovenulosa bark against Fusarium solani. Microbial pathogenesis, 56, 8-15.

Serrato-Diaz, L. M., Rivera-Vargas, L. I., \& FrenchMonar, R. D. (2014). First report of Diaporthe pseudomangiferae causing inflorescence rot, rachis canker, and flower abortion of mango. Plant disease, 98(7), 1004-1004.

Simić, A., Soković, M. D., Ristić, M., GrujićJovanović, S., Vukojević, J., \& Marin, P. D. (2004). The chemical composition of some Lauraceae essential oils and their antifungal activities. Phytotherapy Research: An International Journal Devoted to Pharmacological and Toxicological Evaluation of Natural Product Derivatives, 18(9), 713-717.
Summerell, B. A., Salleh, B., \& Leslie, J. F. (2003). A utilitarian approach to Fusarium identification. Plant disease, 87(2), 117-128.

Trần Nhân Dũng, Nguyễn Thị Pha \& Đỗ Tấn Khang (2012). Công nghệ Di truyền. Nxb. Đại học Cần Thơ.

Tripathi, P., Dubey, N. K., \& Shukla, A. K. (2008). Use of some essential oils as post-harvest botanical fungicides in the management of grey mould of grapes caused by Botrytis cinerea. World Journal of Microbiology and Biotechnology, 24(1), 39-46.

Wilson, C. L., Solar, J. M., El Ghaouth, A., \& Wisniewski, M. E. 1997. Rapid evaluation of plant extracts and essential oils for antifungal activity against Botrytis cinerea. Plant Disease. 812: 204-210.

Zakaria, L., Chik, M. W., Heng, K. W., \& Salleh, B. (2012). Fusarium species associated with fruit rot of banana (Musa spp.), papaya (Carica papaya) and guava (Psidium guajava). Malaysian Journal of Microbiology, 8(2), 127-130.

Zhang, Z., Han, X. M., Wei, J. H., Xue, J., Yang, Y., Liang, L., ... \& Gao, Z. H. (2014). Compositions and antifungal activities of essential oils from agarwood of Aquilaria sinensis (Lour.) Gilg induced by Lasiodiplodia theobromae (Pat.) Griffon. \& Maubl. Journal of the Brazilian Chemical Society, 25(1), 20-26. 